\title{
TWO POEMS
}

\author{
Alfonso Manalastas \\ alfonsomanalastas@gmail.com
}

\begin{abstract}
About the Author
Alfonso Manalastas is an op-ed contributing writer, a spoken word artist, and a poet from Butuan City, now based in Manila. He was accepted as a poetry fellow for two national writers' workshops. His poems have appeared or are forthcoming in several journals including Likhaan: The Journal of Contemporary Philippine Literature, Quarterly Literary Review Singapore, Cha Asian Literary Journal, Voice \& Verse Poetry Magazine, and Cordite Poetry Review, among others.
\end{abstract}




\section{A STUDY OF GRIEF}

I.

You walk over to an empty bar stool,

Etta James blaring from a speaker

some honeyed words uttered

with a kind of eloquence

made possible only

by rain,

tiny droplets drumming

beats to a window, tapping

Morse code for are you alright?

where a hooded grief

takes the seat next to yours.

You do not welcome grief's company,

but his is a language where no

means yes and yes, anyway,

sips gold liquid and insists

small talk while you spit

blood with every answer

from your alcohol-parched mouth,

his line of questioning

a forceful inquiry

into your joy:

But why? You have

so many reasons to be happy. 
II.

Here is a pamphlet.

Like many of its kind,

it will tell you what to do.

It will know exactly what to do.

It will tell you of resilience

and laughter in children's lungs

as they drink gutter water

and play naked through the flood.

It will tell you of lost people:

lost mothers, fathers, of lost limbs,

how hope is a blue pill

you purchase on eBay,

drink knowing that the world

is far too tired to have any room left

for grief, and you will

believe it. You will

believe it when it tells you

to take grief in a box,

ship grief off somewhere distant,

limpid cold, except

everything we send skyward

eventually finds its way back.

You are lucky if it doesn't land

on your delicate head. 
III.

Of all things,

grief understands this most:

the only thing that separates

the departed from the disappeared

are the footprints pressed

on moist terrain.

Welcome to the factory of alleged virtues.

Here, everything you've lost

is found, only better.

Like polished chrome, watch

as grief glistens

in the high tide of the morning,

on stage at a talent show,

dripping wet from a pulpit

over Sunday's homily.

Grief comes to you

unabandoned,

unabashed,

weighs your pockets down

heavy as a missing organ

and yet shinier than ever. This

is where grief comes to die,

to be reborn and baptized

new; a teething infant

eager to suckle your light,

swirl you gentle on his tongue

as you dissolve. 


\section{PAINT BY NUMBERS AS VAN GOGH}

I once was asked on a job interview to describe the color blue to a blind man, to which I responded with a resounding no, I said

what sick man would I be if I lied? The truth is, who knows for sure how blue looks? Like right now, as I glance at the sky hand-painted on this marvelous box, I see a flurry of blueness - eight different kinds numbered differently, the opacity to which they've found their resolve.

Some even a little green. You can place next to it a picture of the sea perched perfectly still, and I wouldn't know the difference for what is the sky

but just an ocean without gravity to hold it back? Eleven stars and a moon-now this, I can tell clearly, is a starry night, an approximation

of all the dark we've abandoned in the day, blueness whirling around yellow dots as if to devour them. Such carnivorous display twinkling above cities

whose hues and pigments pulsate under the tyranny of math-three for blue, four for another kind of blue, and so on. So tell me, 
how am I to describe the color blue to a blind man in all its forms? Six is also blue, and so is seven. Instead, I turn to the cypress tree

black and sullen in its singular hush of dark, its tree bark clawing up the rectangular frame as if to say here dear blue, devour me, too. 